\title{
Quantification of mobbing in the Mexican financial sector from a gender perspective
}

\author{
Cuantificación de mobbing en el sector financiero mexicano desde \\ la perspectiva de género
}

\author{
Mara Maricela Trujillo-Flores / martruj7@hotmail.com \\ Fernando Lámbarry-Vilchis / flambarry@ipn.mx \\ María de la Luz Valderrábano-Almegua / mvalderrabano@ipn.mx \\ Instituto Politécnico Nacional, México
}

\begin{abstract}
Mobbing is a gradual and progressive process in organizations that affects the efficiency and health of their workers. Its incidence and prevalence has been of an increasing interest in the specialized literature, in order to take organizational measures to prevent, control and eradicate this phenomenon. The objective of this research, with a descriptiveexplanatory cutting, is to quantify mobbing through the MVR model, in an organization of the Mexican financial sector from the perspective of gender. We conclude that high levels of mobbing exist in the institution, being situational factors and identity the ones that most influence on mobbing; it was verified that feminine gender is the most affected.
\end{abstract}

Key words: quantification of mobbing, financial sector, gender perspective.

Resumen: Mobbing es un proceso gradual y progresivo en las organizaciones que afecta su eficacia y la salud de sus trabajadores. Su incidencia y prevalencia ha sido de creciente interés en la literatura especializada, con el fin de adoptar medidas organizacionales para evitarlo, controlarlo y erradicarlo. El objetivo de esta investigación de corte descriptiva explicativa es cuantificarlo a través del modelo MVR en una organización del sector financiero mexicano, desde la perspectiva de género. Se concluye que existe mobbing con niveles altos en la institución, siendo los factores situacionales y los de identidad los que más inciden en él y se confirma que es el género femenino en mayor grado el afectado.

Palabras clave: cuantificación de mobbing, sector financiero, perspectiva de género. 


\section{Introduction}

Mobbing is referred to in different ways: bossing, an equivalent to power abuse by line managers; whistleblowing or harassment against those who have complained about irregularities in the company; stalking, referring to harassing behavior, or ijeme, a Japanese term referring to school hazing but extrapolated to the workplace (Piñuel y Zavala, 2001; Hirigoyen, 2001; López-Cabarcos et al., 2008). The key features that differentiate mobbing from any other type of interpersonal conflict in the workplace are three: duration, repetition and the asymmetrical relationship between parties. Einarsen et al. (2003) have conceptualized mobbing as harassing, offending and socially excluding someone or negatively affecting their work tasks, repeatedly, for a while. The harasser takes the opportunity provided by the organizational situation to channel a series of psychopathic impulses and tendencies (Piñuel y Zavala, 2001). The emergence of mobbing can result from various causes in the workplace (Hirigoyen, 2001).

The quantification of the phenomenon has been carried out in different contexts; examples of this are: the Leymann studies, conducted in various sectors of the Swedish population (1990, 1996, 1997); Adams and Crawford (1992), and Baron-Duque (2003) in the service sector; Lopez, Hoel and Zapf (1994) in the administrative context; Zapf, Knorz and Kulla (1996) in the medical field in the United States and Sweden; Langner (1996) in the metallurgical sector; Quine (2000) in the construction industry, services and tourism; Piñuel y Zavala (2001) in health, education and economic sectors; Hirigoyen (2005) in women with different social backgrounds; Van Dick and Wagner (2004), and González de Rivera (2005) in the health sector; while Björkqvist, Osterman and Lagerspetz, (2005) in education. More recently, bullying has been studied from the perspective of gender, Moreno-Jiménez et al. (2005) concluded that being a woman poses a greater potential risk of suffering it; López-Cabarcos et al. (2008), Justice (2007) and Alderete-Rodríguez et al. (2006) agreed that it occurs to a greater extent among women than among men.

However, in the international literature, one notices uneven patterns of quantification, use of dissimilar study subjects, in addition to methodological differences (Mikkelsen and Einarsen, 2001; Salin, 2001), and still scarce differentiator studies of gender, even in economic sectors, such as the financial one, which is on the fringes of them. 
In Mexico, the picture of mobbing in organizations and institutions is devastating due to the scarcity of studies on its measurement; examples of this are financial institutions, in which, because of their conditions, job competitiveness and inegalitarian organizational culture (Cruz, 2014), mobbing presumably would exist. Therefore, the objective addressed by this research is to quantify mobbing under the MVR model and from a gender perspective in a Mexican financial institution. The research has the following format: introduction, contextual framework, theoretical framework, methodological framework, results, analysis of results and the conclusions for the organization.

\section{Characterization of the financial sector in Mexico}

The Mexican financial system can be defined as the set of laws, regulations, agencies and institutions that collect, manage and channel investment, savings within the corresponding legal framework of the country. According to the activities performed, it is divided into five sectors: Banking; non-Banking; Stock Exchange; Derivatives; and, Pension; directly and indirectly regulated by the Secretariat of Finance and Public Credit (Secretaria de Hacienda y Crédito Público) through the Article 28 of the Constitution and the laws of credit institutions, the regulations for public service banking and credit, the Bank of Mexico, the financial groups and the general of organizations and credit-auxiliary activities (Gutiérrez, 2012).

Regarding the quality of jobs offered by this sector, which remains depressed in the world, with a loss of nearly 300,000 posts only in the United States, Britain and Japan, in Mexico hiring rises but focuses on staff working under the scheme of outsourcing (Cruz, 2014), official figures indicate that this type of employees increased $98.1 \%$ in the same period (2007-2014), with an absolute number of 57, 000, 97 workers (Bank of Mexico, 2014).

However, the Mexican banking system has been questioned for years due to its poor quality service, a reflection of organizational problems. It is noted that multiple jobs are generated in them although poorly paid and with long working hours, despite the foregoing and because of the unemployment in the country there are several people who want these positions, producing competitiveness between them. Another peculiarity of financial structures is that they are mostly large and highly bureaucratized with a poor working environment, which encourages the conflict, all of them factors that presumably would foster mobbing inside them. 


\section{Aspects that originate mobbing at the workplace}

The substrate that favors the appearance of this type of behavior is linked to two aspects: the organization of work and the management of conflicts in the workplace. In this regard, Leymann (1996a) says that the causes of mobbing are in the organization itself and, more specifically, in the organization of the tasks and the aspects of leadership. Hirigoyen (1999) says that mobbing thrives when there are factors such as the dehumanization of labor relations, the omnipotence of the company and its complicity with the stalker. For López, Vázquez and Montes (2012), there are social and psychological components in the organization, the victim and the harasser that cause the appearance of the phenomenon. Moreover, empirical studies indicate that mobbing is not any phenomenon but a gradual development process (Einarsen, 2000; Zapf and Gross, 2001). During the early stages of the process the victims undergo indirect aggressive behaviors, of discrete nature; they are isolated and avoided by means of public excessive criticism and humiliation.

The quantification of the phenomenon has been performed in different settings and variables. Illustrating the aforementioned, we have works by Leymann (1996a, 1997), who places his research in different sectors of Swedish population, using variables inherent to the context. Adams and Crawford (1992) placed their work in the service sector, using variables such as the presence of violence and the intensity of it. Hirigoyen (2005) manages female patients from different social classes, using variables of family violence as intimidation, terror and momentum. From 2001 to 2010, Piñuel y Zavala conducted studies in different sectors such as health, education and economy; his most frequent variables have been organizational factors and factors specific to the organization, leadership and cognitive variables. Moran-Astorga (2006) turns his work to the legal aspect of the phenomenon, using variables of frequency, incidence, and legal components. Baron-Duque (2003) has ventured into various service organizations using variables such as leadership, communication and organizational factors. González de Rivera (2005) studied the health sector, with variables such as physical health, emotional health and mental health. Björkqvist, Osterman and Lagerspetz (2005) resorted to members of the Finnish Federation of Municipal Authorities and prison staff using variables such as persecution at work and environment and organizational climate. Einarsen and Hoel (2001) have dabbled in various business sectors in Britain, using variables such as conflict, interpersonal relationships, personality factors and values. 
The quantification model studies analyzed for this research were those of the following authors: Langner (1962), who developed a model as part of Midtown Manhattan, aimed at assessing psychiatric disorders using variables such as actions to discredit workers, self-esteem and characteristics of the organization. Hoel and Zapf (1994) conducted a questionnaire for the administrative sector. Leymann (1996a) made his first studio in the Swedish National Board of Occupational Safety and Health in Stockholm, and later quantifies the phenomenon in various European occupational sectors. Zapf et al. (1996) developed their work in the medical field in the United States and Sweden. Langner (1996) designed an instrument to assess the health of the metallurgical sector. Einarsen et al. (1997), their scale enabled the evaluation of different scenarios in Britain, Germany and Scandinavian countries. Quine (2000), his research has quantified the sectors of construction services and tourism. Piñuel y Zavala (2001) assessed the education sector with different subjects. Knorz and Zapt (2003) addressed the health sector. Björkqvist et al. (2004) worked in the education sector, as well as Van Dick and Wagner (2004). Finally, González de Rivera (2005) conducted his research in the health sector.

As observed, the models have been used in various sectors with different study subjects and something noticed is that only the instrument of Björkqvist et al. (2004) uses women from the basic education sector as a subject of study.

\section{Mobbing and gender}

Gender is an important variable in relation to the mobbing phenomenon. However, there seems to be no consensus to whether women are more affected by these processes than men, or vice versa. For Leymann (1996b) the phenomenon does not yield significant differences; his research shows $45 \%$ men and 55\% women. Gender differences in mobbing have been studied under different aspects such as prevalence, incidence, identification of adopted behavior, causal attributions, health consequences, the response of the victim and strategies to cope with it, frequency and duration of harassment, among the most common.

In a study by Alderete-Rodríguez et al. (2006), prevalence was higher in women $(83.6 \%)$ than in men $(79.5 \%)$; the same is concluded in the study of Moreno-Jiménez et al., (2005) for whom being a woman seems to be a potential risk when suffering harassment. Women $(24.4 \%)$ would be more harassed than men $(16.9 \%)$ and the difference would be statistically 
significant (Justice 2007). López-Cabarcos et al. (2008) and Olaffson (2004) indicated prevalence in their findings among men and women, being in any case slightly higher in women.

Norway, Sweden and Finland are cultures in which differences in power and status are rare among individuals in different formal and informal positions within organizations. These countries may thus have smaller gender differences compared to countries such as France and Spain, which have been identified as countries with the largest imbalances of power in organizations (Hofstede, 1980). Hofstede says that Scandinavian countries have more egalitarian and feminine value-oriented cultures. When interpreting gender differences, it should not be forgotten that, in many cases, the work environment facilitates the appearance of this type of discrimination due to inequalities in it (Moreno-Jiménez et al., 2005).

Another explanation for the gender difference is provided by Salin (2003a), who states that those individuals with less social power, such as ethnic minorities or women, may feel more intimidated and be more sensitive to interpersonal conflicts, conceiving thus a greater proportion of conflict situations as bullying.

\section{Prevalence of mobbing}

The prevalence of mobbing is understood as the process of assessing the number of employees of an organization that are affected by it, with specified duration and frequency.

The literature has identified three main approaches in collecting data on prevalence. The first, called the operational method, is an approach developed by Leymann (1992), in which respondents are asked following an inventory of negative behaviors identified with mobbing. A second method is the subjective method (Einarsen, 2000), which asks the persons to indicate, based on a stated definition, whether they feel exposed to mobbing. The third approach, less employed, is one that uses not only victims, but also those who are considered aggressors when studying prevalence. Both parts of the relationship are questioned and the results are compared in pairs (Vartia and Hyyti, 2002; Salin, 2001; Vartia, 1996).

Using the operational method by Einarsen and Skogstad (1996), with industrial workers, and Huber et al., (2001), with financial institutions ( $\mathrm{n}=$ 427 ), it was obtained a $1 \%$ to $2 \%$ prevalence in Norway and the Netherlands, respectively. Hubert et al. (2001) and Hubert and Veldhoven (2001) weighed 
for production offices (representative sample) a 4.4\%, and for industry, education, government, and service organizations $(\mathrm{n}=66764)$ a $2.2 \%$. Einarsen and Skogstad (1996) quantified relatively low $(n=1470) 0.6 \%$ percentages with university employees and $(n=172) 2.9 \%$ in commerce. Also, Einarsen et al. (1998), with a representative sample of teachers ( $\mathrm{n}=$ 745), reported a 3\% prevalence. Nielsen et al. (2009), with a sample of 2.539 Norwegian employees, reported prevalence between $2 \%$ and $14.3 \%$.

Likewise in Sweden, Leymann (1996b) obtained a 3.5\% prevalence in administrative employees and in Austria, Niedl (1995) found percentages between $26.6 \%$ in the sample $(n=365)$ and $7.8 \%$ in the health sector, and with employees from a research institute $(n=63)$, received $17.5 \%$. However, Vartia (1996) reported prevalence rates of $10.1 \%$ with city employees. Salin (2001) found 1.6\% with business professionals and Vartia and Hyyt (2002) obtained $20 \%$ with prison officials, all conducted in Finland.

\section{Incidence of mobbing}

The incidence of mobbing is defined as the persistence of hostile behaviors with protracted nature in periods with no less than six months and their influence in the work environment (Leyman, 1996; Varta, 1996).

Existing data about it can be found in the Third European Survey on Working Conditions, which expressed a figure of $9 \%$ (12 million people) of possibly affected population (Paoli and Merllié, 2001). In the aforementioned survey, but now in 2008, it is stated that $5.6 \%$ of workers have experienced the phenomenon (Survey of Quality of Life at Work, 2008). From the exercise conducted by the Ministry of Labour and Social Affairs in Spain it appears that between $50 \%$ and $60 \%$ of absenteeism is caused by work stress, mobbing and burnout. The cost is noticeable since it amounts to 20 million Euros at least throughout the European Union (EU, 2004). Likewise, the International Labour Organization (ILO) says that the price of health problems related to work, including stress and mobbing, represents $3 \%$ of the gross domestic product (GDP) of the European Union (ILO, 2009).

It is to be noted that the phenomenon affects all sectors; Brooks and Perot (1991) reported that $88 \%$ of college-attending women declared having witnessed it, but only $5.6 \%$ have admitted to experiencing it. Referring to other productive sectors, Di Martino et al. (2003) reported the following values: public administration and defense $14 \%$; education and health $12 \%$; hotels and restaurants $11 \%$; transport and communications $10 \%$; agriculture 
and fishing 3\%. However, when reviewing the data on this point, not all the studies agree on these sectors being the most affected (Einarsen and Skogstad, 1996; Einarsen et al., 1994). This establishes the need to make estimations about the effect on other sectors that could alert us about the extent of the problem and the characteristics of each economic sector (Di Martino et al., 2003; Einarsen, 2000; Einarsen et al., 1994).

\section{Theoretical justification of variables}

The justification of the variables used in this research is done with reference to various authors and their empirical studies.

Situational factors. Leymann (1993) indicates that mobbing is strongly linked to many elements of the environment and the organization of work, being more common in large, bureaucratic organizations. Triggers of the phenomenon are: performance of the working groups on the victim and people around them, role conflict, role ambiguity, high job demands and low control of the task; all of them are affiliated with situational factors and have been associated with increased rates of the phenomenon (Thylefors, 2007; Einarsen et al., 1994).

Factors specific to the organization. Zapf and Gross (2001: 89) use this variable in their research defining the factors specific to the organization as "events occurring since the conflict intensified by the lack of adequate organizational maneuvers, their increase will depend on the frequency of their occurrence and foremost of management". This variable is also used by Einarsen (2000), Einarsen et al. (1994), and Di Martino et al. (2003). Similarly, it is quoted in specific studies: Einarsen (2000), Zapf and Gross (2001) and Einarsen et al. (2003).

Factors of personal identity. Hirigoyen (2002), when analyzing the harasser, associates personality disorders (paranoid, psychopath and narcissistic) with prolonged behavioral patterns (chronic), which are the cause of the lasting problems with work and interpersonal relationships; it has also been reported by Gil-Monte et al. (2006).

The structuring of the theoretical framework revealed diversity of variables, contexts, unequal quantification models and use of dissimilar subjects. There is no agreement among experts when presenting their empirical results on prevalence and incidence rates, as these vary considerably from one country to another and even between the results from several researchers in the same place. Another interesting point is that there are 
methodological disparities between the studies in different countries as reported by Mikkelsen and Einarsen (2001) and Salin (2001). Another difference is the diversity in the method used to collect data, being the operational and subjective methods the most used.

This leads to carry out more intensive work on the phenomenon in order to obtain information about each of the previous aspects, as there are many gaps that encourage research, especially in emerging countries like Mexico, where it lacks representative fieldwork that allows filling in the aforementioned voids. Therefore, the objective this research addresses is the quantification of mobbing under the MVR model for the discussion of its variables in the financial sector.

\section{Methodology framework}

The study was performed with the instrument called MVR. Designed and validated for a Mexican context, this tool used in its construction the following variables: situational factors, factors specific to the organization and identity factors. The instrument obtained a Cronbach's alpha of 0.928 and a 0.9876 reported reproducibility (Trujillo et al., 2009). Testretest reliability was 0.73 . In a previous study, an exploratory factor analysis of the scale (principal components analysis with varimax rotation) was conducted; it suggested the presence of a single factor that explained a $68.67 \%$ of the variance.

\section{Characteristics of the instrument}

The questionnaire consists of 44 items with 5 anchors and evaluates the following three variables through 11 indicators: 1. Situational factors, through two indicators: reduction of communication and restrictions for the victim to maintain normal social contacts; 2 . Factors specific to the organization, with the following indicators: abuse of power, inequality in the division of labor, poor organization in the work, lack of leadership, interpersonal factors, harassment activities that affect the victim related to the poor internal organization and internal factors; 3. Identity factors, with the indicators: discredit the reputation of the victim and reduction of labor occupation of the victim.

Table 1 (in annex) shows the characteristics of the instrument (Trujillo et al., 2008). 


\section{Sample description}

A sample from an organization of the financial sector in Mexico, which employs 1,400 people, was used. At an invitation for the exercise, 200 people attended, of which 160 agreed to answer the MVR instrument. Below are the characteristics of the study subjects.

Sample distribution according to educational level. Participants by level of study had the following: 2 people complete high school (1.25\%); 20 workers with vocational education and training (12.5\%); 95 people with a technical career (59.37\%); 40 workers with a bachelor's degree (25\%), and 3 people with a master degree (1.875\%).

Sample distribution according to gender perspective. The sample consisted of 91 women $(56.85 \%), 69$ men $(43.125 \%)$ and 5 indeterminate subjects (3.12\%).

Regarding the type of contract. It included 115 workers $(71.88 \%)$ in positions of trust and 45 (28.12\%) in permanent positions.

Regarding the experience in the profession. Participants provided the following data: up to 2 years in the job, 15 workers (9.37\%); 4-10 years, 63 workers (39.37\%); $10-15$ years, 31 workers (19,375\%); 16-20 years, 14 people $(8.75 \%)$; and more than 20 years, 37 workers (23 125\%).

Regarding the age range. This was presented as follows: 18-22 years of age, 1 person $(0.625 \%)$; $23-33$ years, 42 workers $(26.25 \%)$; $34-45$ years, 55 people (34.37\%) and older than 46 years, 62 individuals (38.75\%).

Regarding marital status. This was presented as follows: 65 workers were single (40.62\%); 83 were married $(51.87 \%)$; 11 subjects were divorced (6.87\%); and 1 person who did not clarify their status (0.625\%).

\section{Data collection}

In this case the Leymann (1992) operational method was used. The scale used to assess the study variables was integrated into an instrument called "Questionnaire to study mobbing on professionals". The tool consisted of an introduction explaining the purpose of the study and the method to respond the items, some demographic data and other items related to the phenomenon. After multiple sessions with managers, in which the objective of the work, the instrument to assess the phenomenon, the scope and limitations of the research and the liability waiver from them were presented, their consent was obtained. 
The organization, after a thorough study, gave its approval and issued an invitation to its staff to attend a conference on the phenomenon. Subsequently, in an auditorium meeting, the participants were told the objective of the research, received the instrument and it was stated that participation was voluntary. Filling in the questionnaire took them between 8 and 12 minutes, right on data collection began, foliating each sheet for their control. Next, the lecture on mobbing commenced.

\section{Analysis and results}

The psychosocial model used in this research explains $68.67 \%$ of the total variance of bullying, and between $48.7 \%$ and $66.6 \%$ in the different factors that comprise it in general. In this regard, the investigation by Einarsen $e t a l$. (1994) manages to explain the $10 \%$ of the variance in the range of $7 \%$ to $24 \%$ in the various organizational frameworks investigated. Below are the results from an analysis for each quantified variable.

The Situational factors variable marks opportunities and resources that the organization enables in bullying situations, especially in the communication factor, which appears with a significant value. Although it seems that mobbing constitutes an individual syndrome, it represents a consequence of certain work environments, as it is more prone in work environments reflected in conflict situations around the victim (Einarsen, 2000; Einarsen, Raknes and Matthiesen, 1994). Vartia (1996) indicates that miscommunication can lead to deficiency of information, differences in opinion and lack of discussion about goals and tasks; in particular, the first indicator (miscommunication) is highly revealing since it quantified $46.35 \%$ (74 people involved, 50 women, 24 men) to a high value and a $27.15 \%$ (43 affected) with an average value. The second indicator (restrictions for the victim to maintain normal social contacts) shows a severe restriction for the victim to maintain social contacts, being a factor that affects the work environment in a negative way (Einarsen, Raknes and Matthiesen, 1994) reaching a $43.6 \%$ in average value (70 people affected) and $23.8 \%$ (38 people affected) with high values. The variable Situational factors in its total quantification obtained $40.4 \%$ with average values (64 people affected) and $39.1 \%$ with high values (63 people affected).

The Factors specific to the organization variable quantified with an average value of $71.2 \%$ (108 people affected) and with a high value of $23.3 \%$ (37 people affected). The obtained value indicates that the organizational part 
is weak, requiring a review of the indicators to address the work in a more operational way. The indicators show the following values:

Leadership, Ashforth (1994) and Einarsen et al. (1994), which indicates that a leadership not in accordance with the characteristics of individuals can have health impacts; in this case this indicator reached $48.2 \%$ (77 people) with high values and $24.3 \%$ (38 persons) with average values.

Poor work organization contributes to the emergence of Leymann (1993) phenomenon. The sample presented a quantification of $23.3 \%$ (37 people) with high values and $71.2 \%$ (113 people) with medium values.

Poor internal organization: Einarsen (1999) states that it results in frustration and stress in the working group, especially in relation to the rights, duties, privileges and positions. Similarly, Siege (1998) reported that when not suitable, they can become a breeding ground for mobbing. The measurement of the indicator was $34.1 \%$ (55 people) high, and $37.2 \%$ (59 people) medium.

Internal factors: Vartia (1996) and Hubert and Veldhoven (2001) show in their investigations that these factors can cause deficient information, differences in opinion and lack of discussion of goals and tasks; this indicator obtained $42.1 \%$ (67 people) high values and 27.2\% ( 44 persons) with average values.

Interpersonal factors: Björkqvist (1992) explains that interpersonal factors cause stress, frustration and hostility towards weak people as an escape; in this case the indicator resulted in $42.1 \%$ (67 persons) with high values and $27.2 \%$ ( 44 individuals) with medium values.

Inequality in the division of labor: as presented by Dejours (1990), can cause aggression and hostility. In this case the weighing was $32.7 \%$ (52 persons) with high values and $24.5 \%$ (39 persons) with medium values.

Abuse in the exercise of power: as stated by Greiner and Schein (1990), is the way in which the unresolved issues related to it can corrupt not only top management but the entire organization. In this study the measurement was $42.4 \%$ (68 individuals) with high values and $27.15 \%$ ( 43 subjects) with medium values.

In this regard, Salin (2003b) suggests a possible explanatory paradigm, ranking the history of workplace bullying in three groups: necessary, motivating and precipitating. Necessary factors encompass elements that can foster the occurrence of harassment in the first place, but that alone will not have the ability to promote these behaviors. The motivating factors refer to elements necessary for the stalker to consider it worth projecting a harassing 
behavior to harm colleagues or subordinates who are perceived as burdens or threats. Finally, precipitating factors may be related to organizational changes, such as restructuring, downsizing and remodeling. These factors might increase insecurity, thus making it more likely to have harassment processes.

In reference to the Factors of identity variable, its quantification was: for the indicator harassment activities aimed at discrediting the reputation of the victim personally and occupationally the indicator quantified $38.3 \%$ (61 people) with high values and $44.4 \%$ (71 people) with an average value; in reference to harassment activities to reduce the victim's occupation, its quantification was $19.3 \%$ (30 people) with a high value and 46.9\% (75 people) with an average value; in reference to total quantification, it was $37.1 \%$ (59 people) with a high value and $50.9 \%$ ( 81 people) with an average value. Because of the values obtained, the assessment of this indicator is worrisome, since the team was informed that the organization has a policy of integrated management of emotional intelligence. In this regard, MartínDaza and Pérez-Bilbao (2001) state that active coping behaviors, aimed at solving the problem, or measures to control emotional reactions become more effective than misdirected coping behaviors. Meanwhile, Hirigoyen (1999) points out that there is no specific psychological profile of people who are harassed, but rather professional contexts in which bullying takes place more easily. From a psychological perspective it has also been emphasized the study of the phenomenon of whether there is a typical psychological profile of the perpetrator and it is said that certain psychological profiles are prone to harassing behavior in contexts, while others with stronger moral values resist (Hirigoyen 2001). For Piñuel y Zavala (2001) the pathological root of harassing behavior is in psychopathic, narcissistic and paranoid traits that are usually present.

The total mobbing in the organization variable indicates there are 92 people $(60.6 \%)$ affected with an average value according to the scale used (18 men and 74 women) and 48 people (32.1\%) are reported with a high value (18 men and 30 women), which means that mobbing is present in the organization and its quantification is high and it is the feminine gender which presents it to a greater degree. In reference to other factors that relate to gender such as performed occupation, years of experience, employment status and type of contract, the report is:

Occupation. The group in which the phenomenon is most noticed is the one of those who hold only a high school diploma because they quantified with $80 \%$ of average values, followed by those with a bachelor's degree with 
a value of $84.6 \%$ with average values also; another fact is that $66 \%$ of the mentioned subjects are women.

Years of experience. In relation to years of experience, it was obtained that the most affected group was that of $4-10$ years with $80 \%$ on average, followed by the group of 16-20 years with $69.6 \%$ also with high quantification values. It is significant that from the first affected group $42 \%$ are women and from the second $48 \%$ affected are also women.

Occupational status. The data show that a very large group of participants in the research hold a subordinate status in the hierarchy (80\%). The aforementioned role is occupied to a greater extent by women $(65.4 \%)$ than by men (14.6\%). In reference to control status, these are occupied by men. Referring to senior management (20\%), two thirds are occupied by men and only a third by women.

Type of contract. The most significant values were more impairing in the sector with a permanent position with a $75 \%$ average value and $48 \%$ of these were women.

The data above are troubling because they suggest that the organization permits the phenomenon and verify that this is exercised more in the group of women (from their underrepresentation in senior posts). However, the masculine gender is not exempt from this, there are factors proper to the organization which are more relevant for suffering mobbing, more authoritarian and oppressive environments, implying that some of the factors above are beyond gender status, which eventually will provoke and encourage it, particularly in relation to the type of contract, which would be empirically greater in temporary workers than in the permanent ones and in those with a different working status.

\section{Limitations of the research}

The presented results and the exposed explanatory suggestions should be taken into account considering methodological limitations, mainly the sampling presented in the research. One limitation of this study was the low number of participants in relation to the total workforce. Added to this is the way of data collection through an invitation, which could bias the results. Nevertheless, these conditions are common in this type of study (Björkqvist et al., 1994; Einarsen, 2000). We should also address the transversal quantitative methodology used, which in spite of providing data on the correlation between different factors of the work environment and 
the prevalence of different psychosocial pathologies, does not permit causal inferences (Einarsen et al., 1994), therefore it is not possible to determine if the work environment of the organization is an antecedent or a consequence of bullying (Vartia, 1996). In order to increase the understanding of the processes and factors leading to the occurrence of mobbing qualitative, longitudinal (Salin, 2003b) and transcultural studies (Einarsen, 2000) should be conducted.

\section{Conclusions}

The occurrence of mobbing in an organization somehow exists within the culture elements that allow and even encourage such behavior. The harasser feels they have the implicit support of their superiors to act in such manner. Therefore, a conclusion that can be outlined in the organization of financial sector analyzed is that the phenomenon is present with high incidence and prevalence, where women as a group are heavily afflicted and possibly affecting the productivity of this group.

We know there are situations, contexts, and even societies that favor mobbing, however, even if we all can be exposed to them and be either victims of aggression or aggressors, certain personal characteristics and situations we face can promote more effectively the attacks or prevent them, because even when immersed in perverse systems we may not develop malicious behavior.

Whether we are aware of this, the fact is that determining which factors are intervening in a particular situation of mobbing is very difficult because the deeds take place in secret, victims become embarrassed and end up feeling guilty of what occurs, and colleagues (witnesses) remain silent for fears of being next. All these will lead to a series of consequences at a personal, organizational and social level (Kasl and Cooper, 1997).

According to authors such as Leymann (1996), Piñuel y Zavala (2006) and Baron-Duque (2003), there are many variables embedded in the phenomenon as this is multi-causal. The instrument used in this research was designed with the most recurring variables of work scenarios in public organizations in Mexico (Trujillo et al., 2008).

In relation to the variables used, it is established that situational variables contribute to a large extent to the origin of this syndrome in respect to other, with $39.1 \%$, however closely followed, with $37.1 \%$, by the identity variable. One of the key elements to understand mobbing necessarily transits by analyzing the organizational variables and specific factors that 
identify the occurrence of the phenomenon. Nevertheless, without denying the importance of the role that individual factors of identity can play, the psychosocial factors indicate in many cases that the work environment, in addition to transmitting certain attitudes and values implicit in the culture of the organization, provides the enabling context for harassment to occur. What has been presented highlights the need for further research on the dynamics and processes underlying bullying, requiring a model that takes into account the role played by the various organizational factors associated with bullying.

As noted, the data presented in this research suggest that organizational variables are influencing factors in the process of psychological harassment at work. One of the key findings of the work, and there are hardly any previous data in the literature, is the predictive ability of the type of employment contract on psychological harassment. The results show that temporary contracts or so-called positions of trust are associated with bullying, as the negative beta indicates an inverse relation with stable contracts or permanent positions. In this regard, Quinlan (1999) argues that the increased use of subcontractors in organizations increases tension within organizations and among peers, because the outsourced personnel may be forced to work at a higher rate in order to ensure a prospective position in the company, coming into conflict with peers. Corroborating these suggestions, in a German study, Knorz and Zapf (1996) found that those temporary workers suffered more bullying behaviors than those with a fulltime contract.

Likewise, Baron and Neumann (1996) found similar results providing evidence that the use of part-time workers was a significant predictor of aggression in the workplace. The study indicates the opposite, since the most affected people were those who hold a position of trust obtaining a $75.7 \%$ average value, suggesting that the organization is looking for a way to separate them from it.

Mexico cannot make strong statements; not even suggesting trends about the phenomenon as it lacks significant fieldwork. It should be considered that one of the limitations of this study was the representativeness of the sample, so making generalizations to other organizations in the same or a different production sector should consider this reserve. Based on this, it is possible to delineate, for future research, to consolidate representative samples in organizations of other economic sectors to quantify mobbing and to implement measures, guidelines and institutional policies to prevent, control and eradicate it. The study on gender quantified that the female group 
Mara Maricela Trujillo-Flores, Fernando Lámbarry-Vilchis y María de la Luz Valderrábano-Almegua. Quantification of mobbing in the Mexican financial sector from a gender perspective

in each variable was always the most affected, which was expected, but the hardest part was that the problem is always ignored if the victim is a woman.

\section{References}

Adams, Andrea and Crawford, Neil (1992), Bullying at work: How to confront and overcome I, London: Virago.

Alderete-Rodríguez, María et al. (2006), “Acoso psicológico en el trabajo: ¿Un problema de género?”, in Enseñanza e Investigación en Psicología, year 11, no. 1, Mexico: Universidad Veracruzana.

Ashforth, Blake (1994), "Petty tyranny in organizations: A Preliminary Examination of Antecedents and Consequences", in Canadian Journal, vol. 14, no. 2, Canada: Wyley Library.

Banco de México (2012), Reporte sobre el sistema financiero, México: SHCP.

Baron, Robert and Neuman, Joel (1996), "Workplace violence and workplace aggression: Evidence on their relative frequency and potential causes", in Aggressive Behavior, vol. 22, no. 3, New Jersey: John Wiley \& Sons.

Baron-Duque, Miguel (2003), La espiral del Mobbing, Valencia: Fundación de la Comunidad Valenciana para la Prevención de Riesgos Laborales.

Björkqvist, Kaj, Österman, Karin and Lagerspetz, Kirsti (2005), "Sex differences in covert aggression among adults", in Aggressive Behavior, vol. 20, no. 1, New Jersey: John Wiley $\&$ Sons.

Björkqvist, Kaj, Österman, Karin and Lagerspetz, Kirsti (2004), "Social intelligence - empathy = aggression?", in Aggression and violent behavior, vol. 5, no. 4, Finland: Elsevier.

Björkqvist, Kaj (1994), “Aggression among university employees”, in Aggressive Behavior, no. 5, vol. 20 (in Einarsen, 1999).

Brooks, Jeff and Perot, Annette (1991), "Reporting sexual harassment: Exploring a predictive model", in Psychology of Women Quaterly, vol. 15, no. 1, Sweden: Sage Journals.

Cruz, Laura (2014), El outsourcing en el sector bancario en México, Mexico: Instituto Politécnico Nacional.

Dejours, Christophe (1990), Trabajo y desgaste mental: Una contribución a la Psicopatología del Trabajo, Buenos Aires: Humanitas.

Di Martino, Vittorio, Hoel, Helge and Cooper, Cary (2003), Psychosocial risk factors and work-related bullying: interventions, in European Week for Safety and Health at Work, 2002, European Agency for Safety and health at Work, Bilbao.

Einarsen, Stale, Hoel, Helge, Zapf, Dieter and Cooper, Cary (2003), “The concept of bullying at work", in Ståle Einarsen, Helge Hoel, Dieter Zapf and Cary Cooper [eds.], Bullying and Emotional Abuse in the Workplace. International perspectives in research and practice, London: Taylor and Francis Books Ltd. 
Einarsen, Ståle and Hoel, Helge (2001), The Negative Acts Questionnaire: development, validation and revision of a measure of bullying at work, in Paper presented at the $10^{\text {th }}$ European Congress on Work and Organizational Psychology, Prague.

Einarsen, Ståle (2000), "Harassment and bullying at work: a review of the Scandinavian approach", in Aggression and Violent Behavior, vol. 5, no. 4, Norway: Elsevier.

Einarsen, Ståle, Raknes, Bjørn, and Matthiesen, Stig (1997), "Harassment at work and victimization of men", in Violence and Victims, vol. 12, no. 3, Bethesda, MD: U.S. National Library of Medicine.

Einarsen, Ståle, Raknes, Bjørn and Matthiesen, Stig (1994), "Bullying and harassment at work and their relations to work environment quality. An exploratory study", in The European Work and Organizational Psychology, vol. 4, no. 4, Erlbaum (UK): Taylor and Francis Ltd.

Einarsen, Ståle, Matthiesen, Stig and Skogstad, Anders (1998), Mobbing OgHarde Personkonflikter, Bullying and Hardh Personalized Conflict, Sigma Forlag, Berger,

Einarsen, Ståle and Skogstad, Anders (1996), "Bullying at work: epidemiological findings in public and private organizations", in European Journal of Work and Organizational Psychology, vol. 5, no. 2, Norway: Taylor Francis.

Greiner, Larry and Schein, Virginia (1990), Poder y desarrollo organizacional, USA: Edic. Addison, Wesley Iberoamericana.

Gil-Monte, Pedro, Carretero, Noelia and Luciano, Juan Vicente (2006), "El síndrome de quemarse en el trabajo (Burnout)", in Grupos profesionales de riesgo, Madrid: Pirámide.

González de Rivera, José (2005), El Mobbing en las organizaciones, Barcelona: Kairós.

Gutiérrez, Aníbal (2012), Estructura del sistema financiero, Mexico: SHCP.

Hirigoyen, Marie-France (2005), El acoso moral en el trabajo, Barcelona: Paidós Ibérica.

Hirigoyen, Marie-France (2002), "Mobbing: definición y límites", in Respuestas al Mobbing en el ámbito laboral, Victoria-Gasteiz: Basque government.

Hirigoyen, Marie-France (2001), El acoso moral, Barcelona: Paidós.

Hirigoyen, Marie-France (1999), El acoso moral en el trabajo y la personalidad del acosador, Valencia: Fundación de la Comunidad Valenciana para la Prevención de Riesgos Laborales.

Hoel, Helge and Zapf, Dieter (1994), "Mobbing en puestos de trabajo de tipo administrativo (Questionario)", in Medicina del Trabajo, no. 5, vol. 6, Madrid: PaperNet.

Hofstede, Geert (1980), "Cultures consequences: International differences in work related values", in European Journal of Work and Organizational Psychology, no. 5, California: Sage.

Hubert, Adrianne and Veldhoven, Marc Van (2001), "Risk sectors for undesirable behavior and mobbing", in European Journal of Work and Organizational Psychology, vol. 4, no. 10, vol. 4, London: Taylor \& Francis.

Kasl, Stan and Cooper, Cary (1997), Stress and health: Issues in research methodology, New York: Wiley.

Knorz, Carmen and Zapt, Dieter (2003), "Workplace Mobbing”, in Cary Cooper and Ivan T. Robertson [eds.], International Review of Industrial and Organizational Psychology, 
Mara Maricela Trujillo-Flores, Fernando Lámbarry-Vilchis y María de la Luz Valderrábano-Almegua. Quantification of mobbing in the Mexican financial sector from a gender perspective

vol. 18, University of Manchester Institute of Science \& Technology, UMIST, U K: John Wiley \& Sons, Ltd.

Knorz, Carmen and Zapt, Dieter (1996), "Mobbing-eine extreme form sozialer stressoren am arbeitsplatz", in Zeitschpift fur arbeits-und organisationspsychologie, vol. 40, no. 1, Germany: Hogrefe Verlag GmbH \& Co.

Langner, Stanley (1996), "The affective revolution in organizational behavior: The emergence of paradigm", in J. Greenberg [ed.], Organizational Behavior: The state of the science, Lenders: Lawrense Science/JaI Press.

Langner, Stanley (1962), Classificazione delle sindromie dei disturbipsichicie comportamentali, World Health Organization, Masson.

Leymann, Heinz (1997), The mobbing encyclopedia. Bullying, The definition of mobbing at workplaces, Paris: Du Seuil.

Leymann, Heinz (1996a), Mobbing, Psychoterror am Arbeitsplatz und wie man sichdagegen webren kann, Rowohlt: Reinbeck bei Hamburg.

Leymann, Heinz (1996b), “The content and development of bullying at work”, in European Journal of Work and Organizational Psychology, no. 5, London: Taylor \& Francis.

Leymann, Heinz (1993), Investigation into the frequency of adult mobbing in a Swedish steel company using LIPT, Questionnaire (unpublished manuscript).

Leymann, Heinz (1992), "Fran mobbning utslagning i arbetslivet (desde la intimidación a la expulsión de la vida laboral), in Pública, no. 4, Stockholm.

López-Cabarcos, Ma. Ángeles, Picón-Prado, Eduardo and Vázquez-Rodríguez, Paula (2008), "Incidencia de los procesos de acoso psicológico entre el personal de administración y servicios del sistema universitario gallego", in Investigaciones Europeas de Dirección y Economia de la Empresa, no. 2, vol. 12, Galicia, Spain.

López, María A, Vázquez, Paula and Montes, Carlos (2012), "Perfil de la víctima de Mobbing en Galicia. Especial atención a las diferencias de género”, in Revista Galega de Economía, vol. 21, no. 1, Santiago de Compostela: Universidad de Santiago de Compostela.

Martín-Daza, Félix and Pérez-Bilbao, Jesús (2001), NTP 476: El hostigamiento psicológico en el trabajo: Mobbing, Madrid, Spain: Ministerio de Trabajo y Asuntos Sociales de España, Instituto Nacional de Seguridad e Higiene en el Trabajo, (INSHT).

Mikkelsen, Eva and Einarsen, Ståle (2001), "Relationships between exposure to bullying at work and psychological and psychosomatic health complains: The role of state negative affectivity and generalized self-efficacy", in Scandinavian Journal of Psychology, no. 43, Scandinavian: John Wiley \& Sons Ltd.

Moran-Astorga, Consuelo (2006), "Relación entre el acoso psicológico y el Burnout", in Revista para la integración y desarrollo de los recursos humanos, vol. 19, no. 199, Logroño: Ciss Praxis.

Moreno-Jiménez, Bernardo et al. (2005), “Antecedentes organizacionales del acoso psicológico en el trabajo: un estudio exploratorio”, in Psicothema, vol. 4, no. 17, Spain: Facultad de Psicología de la Universidad de Oviedo and el Colegio Oficial de Psicólogos del Principado de Asturias.

Niedl, Klaus (1995), Mobbing/bulling am Arbeitplatz, Rainer Hampp: Munich: Verlag. 
Nielsen, Morten, Bjørkelo, Brita, Notelaers, Guy and Einarsen, Ståle (2010), "Sexual harassment: Prevalence, outcomes, and gender differences assessed by three different estimation methods", in Journal of Aggression, Maltreatment \& Trauma, vol. 3, no. 19, Norway: Taylor \& Francis.

Organización Internacional del Trabajo (OIT) (2009), Programa de Actividades Sectoriales. Repertorio de recomendaciones prácticas sobre violencia y el estrés en el sector servicios y medidas para combatirla, Geneva: Oficina Internacional del Trabajo.

Paoli, Pascal and Merllie, Damien (2001), “Third European Survey on Working Conditions in the European Union (2000)", in European Foundation for the Improvement of Living and Working Conditions, Luxemburg: Office for the Official Publications of the European Communities.

Piñuel y Zavala, Iñaki (2006), Estudio Barómetro Cisneros VIII, Madrid: Universidad de Alcalá de Henares.

Piñuel y Zavala, Iñaki (2001), Estudio Barómetro Cisneros II, Madrid: Universidad de Alcalá de Henares.

Quine, Lyn (1999), "Workplace bulling in NHS community trust: staff questionnaire survey", in British Medical Journal, vol. 7178, no. 318, uk: Eprints.

Quinlan, Michael (1999), "The implications of labor market restructuring in industrial societies for occupational health and safety", in Economic and Industrial Democracy, vol. 20, no. 3, Sweden: Sage Journals.

Salin, Denise (2003a), "Prevalence and forms of bullying among business professionals: a comparison of two different strategies for measuring bullying", in European Journal of Work and Organizational Psychology, vol. 4, no. 10, London: Taylor \& Francis.

Salin, Denise (2003b), "The significance of gender in the prevalence, forms and perceptions of workplace bullying", in Nordiske Organisasjonstudier, no. 5, vol. 3, Brazil: Scielo.

Salin, Denise (2001), Prevalence and forms of bullying among business professionals: a comparison of two different strategies for measuring bullying, in European Journal of Work and Organizational Psychology, no. 10, vol. 4, London: Taylor \& Francis.

Seigne, Elizabeth (2000), "Bullying at work in Ireland”, in Michael Sheehan and Michelle Barker, Charlotte Rayner, (1999) "Applying strategies for dealing with workplace bullying", in International Journal of Manpower, vol. 1, no. 20, UK: Emerald Group Publishing.

Thylefors, Ingela (2007), Syndabockar-Om utstötning och Mobbing i arbetslivet, Stockholm: Natur och Kultur.

Trujillo, Mara et al. (2009), Análisis de variables que inciden en la aparición de los fenómenos psicosociales en las organizaciones públicas mexicas, in VIII Congreso Internacional de la Sociedad Española para el Estudio de la Ansiedad y el Estrés, Ministerio de Salud, Spain: Universidad de Valencia.

Trujillo, Mara et al. (2008), Mobbing un problema de salud laboral y el trabajo decente, 1er. Congreso Internacional en Violencia, Maltrato y Abuso, Víctimas y Victimarios. Un desafío para la interdisciplina, Buenos Aires, Argentina.

Unión Europea (UE) (2004), Encuesta de salud y sus beneficios para la comunidad europea, Ministerio de salud, Spain: Ministerio de Salud. 
Mara Maricela Trujillo-Flores, Fernando Lámbarry-Vilchis y María de la Luz Valderrábano-Almegua. Quantification of mobbing in the Mexican financial sector from a gender perspective

Van Dick, Rolf and Wagner, Ulrich (2004), "Stress and strain in teaching: A structural equation approach", in British Journal of Educational Psychology, vol. 71, no. 2, New Jersey: John Wiley \& Sons.

Vartia, Maarit and Hyyti, Jari (2002), "Gender differences in workplace among prison officers", in The European Journal of Work and Organizational Psychology, vol. II, no. 1, London: Taylor \& Francis.

Vartia, Maarit (1996), “The sources go bullying-psychological work environment and organizational climate", in European Journal of Work and Organizational Psychology, no. 5, London: Taylor \& Francis.

Zapf, Dieter and Gross, Claudia (2001), "Conflict escalation and coping with workplace bullying: A replication and extension”, in International Journal of Manpower, vol. 10, no. 4, Canada: Taylor \& Francis.

Zapf, Dieter, Knorz, Carmen and Kulla, Matthias (1996), “On the Relationship between Mobbing factors, and Job Content, Social Work Environment, and Health Outcomes European", in European Journal of Work and Organizational Psychology, vol. 5, no. 2, Germany: Taylor \& Francis. 


\section{Annex}

Table 1

MVR Instrument validation values

\begin{tabular}{|c|c|c|c|c|}
\hline Variables & $\begin{array}{l}\text { No. of } \\
\text { items }\end{array}$ & Indicators & $\begin{array}{l}\text { Cronbach's } \\
\text { Alpha }(\alpha)\end{array}$ & Reproducibility \\
\hline $\begin{array}{l}\text { Situational } \\
\text { factors }\end{array}$ & 10 & $\begin{array}{l}\text { 1. Decreased communication } \\
\text { 2. Restrictions for the victim } \\
\text { to maintain normal social } \\
\text { contacts }\end{array}$ & 0.8763 & 0.95695 \\
\hline $\begin{array}{l}\text { Factors } \\
\text { specific } \\
\text { to the } \\
\text { organization }\end{array}$ & 17 & $\begin{array}{l}\text { 1. Abuse of power } \\
\text { 2. Inequality in the division } \\
\text { of work } \\
\text { 3. Bad organization at work } \\
\text { 4. Lack of leadership } \\
\text { 5. Interpersonal factors } \\
\text { 6. Harassment activities } \\
\text { affecting the victim related to } \\
\text { poor internal organization } \\
\text { 7. Internal factors }\end{array}$ & 0.9099 & 0.94 \\
\hline $\begin{array}{l}\text { Identity } \\
\text { factors }\end{array}$ & 17 & $\begin{array}{l}\text { 1. Discredit the reputation of } \\
\text { the victim } \\
\text { 2. Reduction of the labor } \\
\text { occupation of the victim }\end{array}$ & 0.87855 & 0.93615 \\
\hline
\end{tabular}

Source: Own elaboration.

Mara Maricela Trujillo Flores. Doctor in Administrative Sciences from National Polytechnic Institute (IPN), Mexico; currently working at Escuela Superior de Comercio y Administración (ESCA), part of IPN. Research lines: organizational development, emotional intelligence, gender and mobbing. Recent publications: "Mobbing Model for Executive Women of a Public Higher Education Institution in Mexico", in Revista Contaduria y Administración, Mexico: UnAm (2014); "Desarrollo de una escala de medición de la percepción en la calidad del servicio en los sistemas de autobuses de tránsito rápido a partir del Metrobús de la Ciudad de México”, in Revista Innovar, Bogota: National University of Colombia (2013); "Diagnóstico del sistema profesional de carrera y certificación de competencias gerenciales 
de los servidores públicos en México", in Estudios Gerenciales, Cali: Icesi University (2013).

Fernando Lámbarry Vilchis. Doctor in Administrative Sciences from National Polytechnic Institute (IPN), Mexico. Ascribed to Escuela Superior de Comercio y Administración, Santo Tomás Unit, Postgradaute Studies and Research Section, IPN. Member of the National System of ResearchersConacyt. Research lines: sustainability, public transport and complexity of organizations. Recent publications: "Mobbing Model for Executive Women of a Public Higher Education Institution in Mexico", in Revista Contaduría y Administración, Mexico: unam (2014); "Desarrollo de una escala de medición de la percepción en la calidad del servicio en los sistemas de autobuses de tránsito rápido a partir del Metrobús de la Ciudad de México", in Revista Innovar, Bogota: National University of Colombia (2013); "Diagnóstico del sistema profesional de carrera y certificación de competencias gerenciales de los servidores públicos en México", in Estudios Gerenciales, Cali: Icesi University (2013).

María de la Luz Valderrábano Almegua. Master in Sciences with specialty on Methodology of Science, ascribed to Centro Interdisciplinario de Investigaciones y Estudios sobre Medio Ambiente y Desarrollo, of National Polytechnic Institute (IPN), Mexico. Work lines: public policies, labor environment in organizations, society and environmental policy. Recent publications: Cuaderno de politica ambiental, Mexico: IPN (2010); Guía de práctica para el diagnóstico de Mobbingen la organización, Mexico: IPN (2011); Medio ambiente, sociedad y politicas ambientales en el México contemporáneo: Una revisión interdisciplinaria, Mexico: Miguel Ángel Porrúa, IPN and Autonomous University of Guerrero (2011).

Reception: July 4th, 2013.

Approval: August 1st, 2014. 
